On the Way to Three-dimension — "Les Demoiselles D'Avignon" by Picasso

\author{
Xiaoyu Kang \\ Central Academy of Fine Arts, Beijing 100105, China \\ DOI: 10.32629/asc.v2i4.523
}

\begin{abstract}
The brilliant modern arts with numerous schools have given birth to numerous masters in art. For many readers and ordinary people, modern art is a conundrum, which bewilder people with extreme linguistic forms and spiritual backgrounds. Besides, it posed challenges to people's aesthetics with revolutionary gestures. Picasso is an important representative figure in modern art and cubism is a major achievement in his exploration of art with far-reaching influence. This paper helps the audience understand the modern art master Picasso and cubism through the study of "Les Demoiselles D'Avignon". Keywords: Picasso, cubism, "Les Demoiselles D'Avignon"
\end{abstract}

\title{
Introduction
}

Born in Malaga, Spain, in October 1881, Pablo Picasso is called "The Greatest Artistic Genius of The 20th Century". Picasso spent his whole life pursuing the innovation of two-dimensional painting with commitments to breaking the bottlenecks of tradition so as to create expressive artistic language. His artistic technique is exaggerated and distorted, which is closely pertinent to the background of the times, as a result, it shows Picasso's rejection of the abnormal interpersonal and class relations in the capitalist society at that time. His artistic style is ever-changing, and his artistic creation has gone through many periods, influencing and promoting the development of many artistic styles and schools of painting in the 20th century.

Cubism is the first new art movement after 1900, which makes the painting to be presented in form of a new style, that is, to express one thing from multiple perspectives in painting at the same time, which has exerted a profound influence on the development of modern art. Picasso's "Les Demoiselles D'Avignon" is rendered as the first work with cubist elements, and even as a pioneering work of cubism. "Les Demoiselles D'Avignon" is Picasso's resistance against the objective image, the last basis of western art since classical times. It shows the multiple meanings of rebellion and dismantling, and promotes the arrival of the thought wave of modern artists. It is an indispensable part of the study of Picasso and cubism.

\section{Process of creation}

April 1904 witnessed the fourth arrival of Picasso to Paris, during which he owned his first own studio, known as the "Laundry Workshop". The new environment changed Picasso's life drastically, which led to new thinking and changes in his style. Between 1904 and 1906, Picasso went through his first classicism and black period, and then he gradually gave his presence to cubism. Before the end of the Rose Period, Picasso had acquaintance with several entrepreneurs who admired his paintings and bought other works. He finally got out of his misery and became rich. The style changed correspondingly - the melancholy image that had lasted for two periods disappeared from the painting. After that, Picasso devoted himself to the study of painting forms, looking for new breakthroughs.

In 1905 Matisse and the Fauvism became popular in Paris as a "Revolution in Painting". But for Picasso, Matisse's work was still a continuation of classical art, expressing traditional content in a system of modern language: love and harmony. So Picasso didn't think he could get far. Unlike Matisse's obsession with color, Picasso focused more on the characteristics of different physical forms and the space around them. In 1906, Picasso gradually began to explore cubism.

After visiting the Museum of Anthropology in Paris in 1907, Picasso was influenced by African black statues and mask art and many underclass people died of venereal disease. He was eager to warn people and judge the society of that time through his pictures. The images in the original art are mostly roughly created with tremendous sensational expressions, which seems to be suitable for the paintings of this theme. At the same time, Picasso tried to break through the traditional painting by disintegrating and reorganizing the painting elements. "Les Demoiselles D'Avignon" was conceived and completed. From the picture, we can also see Picasso's infatuation with the distortion and exaggeration in the original art. What an obnoxious 
title is the "Les Demoiselles D'Avignon"! Do you know why? Avignon has always been a very familiar name to me, a name that has something to do with my life. I used to live in a place close to Avignon, so I used to buy paper and paint there. And, as you know, Max Jacobs's grandmother lived there, and she talked to me a lot about the painting, and of the women. They all lived in a local brothel. "This is Picasso's memory and description of his paintings. Picasso refused to invite all friends and visitors to enter his studio during the painting process, so as not to disturb the painting, and he did not invite friends to watch the painting until it was finished. And everyone was amazed by "Les Demoiselles D'Avignon" — Picasso's painting had changed dramatically in a few months. However, "Les Demoiselles D'Avignon" was not recognized by his friends after the completion and people questioned Picasso's change in creation style, thinking that "Les Demoiselles D'Avignon" is full of absurdity with impenetrability. .

\section{Analysis and appreciation on creation style and picture}

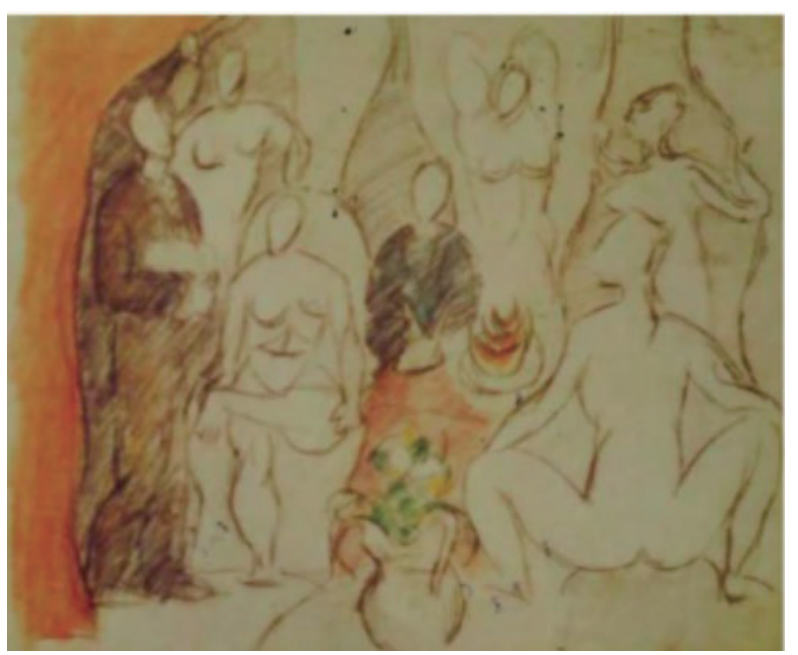

Figure 1. First version of "Les Demoiselles D'Avignon"

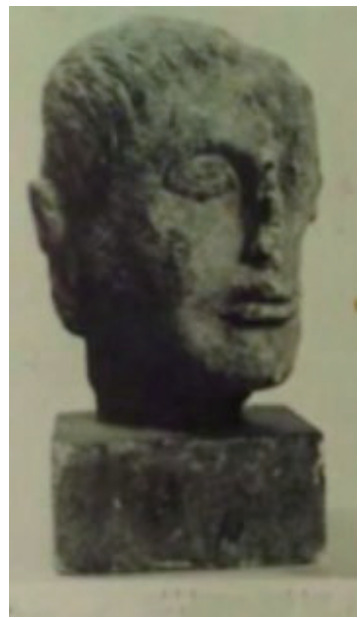

Figure 2. Stone Head

According to research, there were 13 sketches in "Les Demoiselles D'Avignon", the earliest large-scale composition dated from early 1907 (Figure1). Later, it was influenced by primitive art and tried to apply primitive art symbols to paintings. The Medical Student, one of the exercises of "Les Demoiselles D'Avignon", used the Stone Head in the Iberian Peninsula for reference (Figure 2). At the same time, influenced by the composition of Cezanne's famous painting"Water Bath", the second draft was produced in mid-June after adjustment. Picasso removed the two males and changed the direction of the composition to vertical. Compared with the first draft, the second draft has more tension, and the pictures have more abandoned the sense of space of traditional paintings. After that, Picasso adjusted some details of the picture, replacing the facial images of the three girls with the masks of primitive tribes. By August 1907, the final draft was completed.

The processing of pictures of "Les Demoiselles D'Avignon" is drastically made. The five girls were facing the viewer 
either front, side, or standing or squatting. Their naked bodies fully showed their body lines. The powerful lines of the picture completely abandon the softness and harmony of classical portrait painting, and the treatment of the painting background is also full of impact. Whether it is to stare closely at the local details, or to watch the whole will make the viewer had a strong sense of discomfort. Women with ugly appearance and no sensual image are almost unheard of in the past western art and painting, while the two women in the painting of Avignon Girl are still relatively common female images. However, the nose, which is completely lateral, appears on the front cheek as if imposed on the face. On the left of the woman in the middle is a woman with a profile face. Her eyes are in the front at this time. If you look closely at all parts of the body, you cannot distinguish the specific parts, but you can still see the shape of the woman when you combine them. The image of the woman on the right of the center is even uglier. The two naked women have rough facial images. The image of the body facing away from the viewer is matched with a distorted front face, with all parts of the body misaligned. The weirdness and ugliness of the picture make the viewer uncomfortable, but at the same time make people stare at it. Some emotion conveyed in the painting seems to be about to break through the paper. At the same time, the picture presents a single flat, without any line extension and color gradient to reveal the space. The use of color can find a trace of brutalism, grotesque and exaggerated, sharp contrast but not messy, perspective impact is very strong. Picasso described the creation of "Les Demoiselles D'Avignon" as follows: "Les Demoiselles D'Avignon" was created at a certain time on a certain day. I went to the flea market alone. There were so many things in the flea market. But I didn't go. I chose to stay, thinking that something important might be about to happen. Look, those masks are not like those other sculptures, absolutely not, they are molded things, sculptures that exist to fight against everything, against the unknown, against the terrible gods. I've learned that I'm against everything, too. I understand that this is the significance of black people using sculpture, they exist as weapons, to help people get rid of evil spirits, to help them stand on their own feet, I understand why I am a painter."He saw shape as a weapon against the outside world and against all the existing rules.

By careful analysis of the painting, we can find that it revealed brutalism even though Picasso did not approve of Matisse's fauvism. It can be said that "Les Demoiselles D'Avignon" is the result of the fusion and breakthrough of Picasso's pictures and thoughts, which lays a foundation for the development of cubism rules.

\section{Discussion on values}

\subsection{From the perspective of the development of art history}

In the History of Modernist Art, the "Les Demoiselles D'Avignon" described as follows: "Les Demoiselles D'Avignon" is the first cubist work and the symbol of the birth of Cubism."

In the Art History of Cambridge, it is described as follows: "In 1907, one of his startling paintings was 'Les Demoiselles D'Avignon', which was painted in a brothel, and Picasso became the first model of cubism."

In his book, Across the Century — Western Modernist Art, he wrote,"In 1907, influenced by Cezanne s "Bathing Women", Picasso drew from Iberian sculpture and African sculpture to create "Les Demoiselles D'Avignon", which established cubist painting.

The above three sources all consider "Les Demoiselles D'Avignon" as the symbol of the birth of cubism. It can also be known from relevant materials that "Les Demoiselles D'Avignon" is the first recognized cubist work and a masterpiece of Picasso's transition period. But looking back at art history, early cubist paintings were not really a beautiful creation, or even with ugliness. Until the rules of cubism were determined, Picasso's cubist paintings became gradually matured with balanced techniques in color. Picasso did not show the "Les Demoiselles D'Avignon" in public at the beginning of its completion. Therefore, it cannot be regarded as a mature work of cubism directly, but its contribution to the exploration of cubism can not be ignored.

\subsection{From the perspective of commercial value}

In July 1916, nine years after its completion, "Les Demoiselles D'Avignon" was exhibited in public for the first time at the Salon d'Antin in Salomon. Picasso took it and kept it with him until 1924, when Breton and the writer Louis Aragon suggested Picasso to sell it to designer Jacques Dousay for 25, 000 francs. Within a few months of Doucet's purchase, the painting had appreciated in value between 250, 000 and 300, 000 francs. Then, in November 1937, Jacques Seligman \& Company of New York exhibited at its gallery "Evolution of Picasso in 20 Years, 1903-1923", which included "Les Demoiselles D'Avignon"."It was later acquired by the Museum of Modern Art in New York for \$24, 000. There is no public circulation of information since then. But we can still estimate it by looking at other Picasso paintings. In May 2021, Picasso's "Woman At the Window" was sold for \$103. 4 million at Christie's auction house in New York. In 2013, it sold for an estimated \$43. 08 million, less than double the price paid for "Les Demoiselles D'Avignon" 70 years earlier. Meanwhile, 
by comparing the artistic value, market recognition and popularity of the two paintings, we can see the high market value of the painting "Les Demoiselles D'Avignon". At the same time, Picasso co-branded all kinds of commercial goods market sales are very considerable. There are also considerable prospects for combining Avignon Maid with business.

\subsection{From the perspective of conveyed spirit in the picture}

In "Les Demoiselles D'Avignon", the plump bodies of prostitutes are abstracted into geometric shapes and presented to the audience, which was unlike the aged prostitutes portrayed by Rodin and the poor dancers portrayed by Degas, the ugly women portrayed by Picasso is a criticism of reality. Their eyes seemed to tell people something, mocking the ugliness of capitalist society. Goodness, faith and conscience were sold along with the body."They existed only in a small town, while the public lived in a 'philosophical brothel'", which was a cryptic interpretation of the situation: why did they become prostitutes? Were they born so dull and shameless? Did they really mean nothing? Aren't people who are oppressed by class and whose beliefs were shattered by reality were those prostitutes who were raped? Therefore, Picasso's "Les Demoiselles D'Avignon" not only made a great breakthrough in artistic language, but also conveyed a profound spirit, which conveyed Picasso's inner voice. To some extent, the term "Les Demoiselles D'Avignon" extended beyond prostitutes and blacks. The painting not only broke the traditional aesthetics, but also reflected the cruel reality and gave out the voice of confrontation, which had profound realistic significance.

\section{Conclusion}

"Les Demoiselles D'Avignon" is not only a masterpiece of Picasso in transitional period, but also helps us better understand and sort out the changes in his psychology and painting style. At the same time, it is also an important work on cubism. Whether the rebellious thought against everything or the artistic language that surpasses traditional painting, it has exerted profound influence to modern art. In the future, we can further discover and explore the potential value of "Les Demoiselles D'Avignon". On the other hand, whether there is hype and exaggeration in the judgment of cubism value of "Les Demoiselles D'Avignon" is still worth our thinking and research.

\section{References}

[1] Bai Xue. Appreciation of Picasso's "Les Demoiselles D'Avignon"[J]. Short Stories (Original Edition). 2014; (26): 127128.

[2] Liu Xiang."Transformation" of Painting — Brief discussion on Picasso's "Les Demoiselles D'Avignon"[J]. Art Education Research. 2013; 000 (021): 32.

[3] Xu Wei. Great Forerunner - Exploration and creation of Picasso's Painting art[J]. ART AND LITERATURE FOR THE MASSES. 2009; (4): 52-53.

[4] Song Yucheng. Birth of "Les Demoiselles D'Avignon" and its doubt on value[J]. World Art. 2014; 000 (002): 88-94.

[5] Cui Qingzhong. A history of modernist art. Beijing: People's Fine Arts Publishing House; 2000: 49.

[6] Donald Reynolds et al. Cambridge Art History. Translated by Qian Chengdan, Luo Tongxiu. Beijing: China Youth Publishing House; 1994: 209.

[7] Yuan Lin. Across the Century — Western Modernist Art. Beijing: China Workers' Publishing House; $1997: 79$. 